\title{
PENGARUH METODE LATIHAN KONTINU DAN INTERVAL TERHADAP PENINGKATAN DAYA TAHAN AEROBIK PEMAIN FUTSAL
}

\author{
Marfyana Anggun Faisal ${ }^{1^{*}}$, Indrayogi ${ }^{2}$ \\ ${ }^{1}$ SMP Negeri 2 Sukra,Jl. Mekarsari Quarter Pertamina, Indramayu, Jawa Barat, Indonesia, 45258 \\ ${ }^{2}$ Universitas Majalengka, Jl. K. H. Abdul Halim No. 103, Majalengka, Jawa Barat, Indonesia, 45418 \\ *anggunfaisal03@gmail.com
}

\begin{abstract}
Basically, futsal is a game that requires maximum technique and tactics. Therefore, futsal players are required to have optimal endurance so that they always move without experiencing fatigue. However, the problem faced at Club X Soes is the low aerobic endurance of futsal players. The research objective was to determine the effect of continuous and interval training methods on increasing the aerobic endurance of futsal players. The method used is experimental. The research design used One Group Pretest Posttest. The population in this study was 12 futsal players. The sampling technique used total sampling. The research sample consisted of 12 futsal players. This type of research is quantitative research. The data collection technique used the bleep test which was carried out in the initial and final tests. Data processing and analysis techniques use SPSS 24. test result data can be proven which in the initial test results before treatment is given 41.3 and after being given the continuous training method treatment and the interval becomes 45.2 meaning that the test data shows an increase in athlete's endurance 4. Apart from test data, the increased endurance of futsal players is also strengthened from the results of the hypothesis test, the value of $t$-count $=9,326$ is greater than the value of $t$-table $=1.789$ or the hypothesis is accepted. Based on the $t$ value obtained above, it can be concluded that the continuous and interval training method has a significant effect on the endurance of futsal players or in other words the research hypothesis is acceptable.
\end{abstract}

Keywords: Continuous Exercise; Interval Training; Aerobic Endurance

\begin{abstract}
ABSTRAK. Pada dasarnya permainan futsal merupakan permainan yang membutuhkan teknik dan taktik yang maksimal. Oleh karena itu, pemain futsal dituntut memiliki daya tahan tubuh yang optimal agar selalu bergerak tanpa mengalami kelelahan namun permasalahan yang dihadapi pada club $x$ soes adalah masih rendahnya daya tahan aerobik pemain futsal. Tujuan penelitian untuk mengetahui pengaruh metode latihan kontinu dan interval terhadap peningkatan daya tahan aerobik pemain futsal. Metode yang digunakan adalah eksperimen. Desain penelitian menggunakan One Group Pretest Posttest. Populasi dalam penelitian ini dengan jumlah 12 pemain futsal. Teknik pengambilan sampel menggunakan Total Sampling. Sampel penelitian dengan jumlah 12 pemain futsal. Jenis penelitian ini adalah penelitian kuantitatif. Teknik pengumpulan data menggunakan tes bleep test yang dilakukan pada tes awal dan akhir. Teknik pengolahan dan analisis data menggunakan SPSS 24. data hasil tes dapat dibuktikan yang mana pada hasil tes awal sebelum diberikan perlakuan 41.3 dan setelah diberikan perlakuan metode latihan kontinu dan interval menjadi 45.2 artinya dari data tes tersebut menunjukan adanya peningkatan daya tahan atlet 4 . Selain dari data tes, peningkatan daya tahan pemain futsal dikuatkan pula dari hasil uji hipotesis nilai t-Hitung $=9.326$ lebih besar daripada nilai t-Tabel $=1.789$ atau hipotesis diterima. Berdasarkan nilai t hitung yang diperoleh di atas, maka dapat disimpulkan bahwa metode latihan kontinu dan interval berpengaruh signifikan terhadap daya tahan pemain futsal atau dengan kata lain hipotesis penelitian dapat diterima.
\end{abstract}

Kata Kunci: Latihan Kontinu; Latihan Interval; Daya Tahan Aerobik. 


\section{Pendahuluan}

Dalam bermain futsal, pemain futsal bukan hanya mampu menguasai teknik dan taktik saja, melainkan daya tahanpun penting untuk dioptimalkan, karena dengan daya tahan yang maksimal dapat memiliki peranan penting untuk menunjang keberhasilan teknik dan taktik dalam bermain futsal tersebut. Hal ini, seperti dijelaskan menurut Emral (2017) menjelaskan bahwa, daya tahan merupakan faktor fisik yang sangat penting dalam menentukan prestasi atlet, karena daya tahan yang baik maka seorang atlet akan mampu menerapkan teknik dan taktik secara maksimal. Futsal merupakan olahraga permainan bola yang dimainkan oleh dua regu. Seperti yang dijelaskan menurut Narti (2009) menjelaskan bahwa, futsal adalah permainan bola yang dimainkan oleh dua regu dengan satu regunya sebanyak 5 orang.

Daya tahan memiliki hubungan dengan perfoma atlet, baik pada saat berlatih maupun bertanding, pemain futsal yang memiliki daya tahan yang bagus akan mampu bermain lebih lama tanpa mengalami kelelahan. Hal ini seperti diungkapkan menurut Emral (2017) menjelaskan bahwa, hubungan antara daya tahan dan kinerja (penampilan) fisik atlet diantaranya: 1) kemampuan untuk melakukan aktivitas kerja secara terus menerus dengan intensitas yang tinggi dan dalam jangka waktu yang lama, 2) kemampuan untuk memperpendek waktu pemulihan (recovery) terutama pada cabang olahraga pertandingan dan permainan serta, 3) kemampuan menerima beban latihan yang lebih berat, lebih lama, lebih variasi.

Mengacu pada pentingnya daya tahan aerobik terhadap penampilan fisik (performance). Maka dari itu, peneliti mencoba melakukan pra obeservasi untuk mendapatkan data informasi yang berkaitan tentang daya tahan pemain futsal $\mathrm{x}$ soes. Selama proses observasi ada beberapa temuan permasalahan diantaranya pada saat berlatih atlet masih belum optimal dalam melakukan aktivitas latihan fisik yang lebih lama dikarenakan sering mengalami kelelahan. Selain itu, saat bertanding dengan intensitas permainan yang tinggi seringkali atlet mengalami penurunan daya tahan yang cepat dikarenakan kondisinya sudah mengalami kelelahan. Dari beberapa atlet yang diwawancarai mengaku bahwa mereka mudah mengalami kelelahan ketika memasuki 15 menit akhir pada babak kedua. Hasil diskusi dengan pelatih, atlet kurang mendapatkan latihan-latihan untuk melatih daya tahan tubuh. Akibatnya, daya tahan yang dimiliki pemain futsal masih belum maksimal. 
Selain data pengamatan, peneliti juga melakukan tes daya tahan untuk mengetahui daya tahan pemain futsal tersebut. Adapun data hasil tes daya tahan pada pra observasi awal yang penulis lakukan di club futsal x soes dapat disimpulkan bahwa hasil rata-rata tes menunjukan rendahnya hasil daya tahan atlet dibawah kategori rata-rata 20 atlet (100\%) dari 20 sampel. Maka, dapat disimpulkan bahwa atlet futsal di club x soes memiliki daya tahan yang rendah atau dibawah rata-rata.

Mengacu pada permasalahan-permasalahan di atas, peneliti mencoba melakukan upaya untuk memperbaiki dan meningkatkan daya tahan pemain futsal $\mathrm{x}$ soes dengan menggunakan latihan kontinu dan latihan interval. Latihan kontinu merupakan latihan yang dilakukan secara terus menerus. Hal ini seperti diungkapkan menurut Harsono (2018:) menjelaskan bahwa, latihan kontinu yaitu lari terus-menerus tanpa istirahat, dan yang biasanya berlangsung untuk waktu yang lama. Lari terus-menerus yang lebih dari 30 menit dengan tempo yang sedang dibawah ambang rangsang anaerobik akan menghasilkan adaptasi aerobik dengan baik. Menurut Mylsidayu (2015) menjelaskan bahwa, interval adalah waktu istirahat yang diberikan pada saat antar set atau antar seri atau sirkuit atau antar sesi per unit latihan.

\section{Metode Penelitian}

Metode yang digunakan dalam penelitian ini menggunakan penelitian eksperimen. Penelitian eksperimen dilakukan untuk meneliti kemungkinan adanya hubungan sebab akibat diantara variabel dengan memberikan perlakuan. Mengenai metode eksperimen hal ini dijelaskan Menurut Sukmadinata (2013) mengungkapkan, penelitian eksperimental merupakan pendekatan penelitian yang cukup khas. Kekhasan tersebut diperlihatkan oleh dua hal, pertama penelitian eksperimen menguji secara langsung pengaruh suatu variabel terhadap variabel lainnya, kedua menguji hipotesis hubungan sebab-akibat.

Dari paparan di atas, dapat dijelaskan bahwa penelitian eksperimen adalah penelitian untuk mencari tahu hubungan sebab dan akibat atau yang mempengaruhi dan dipengaruhi. Dalam kaitan penelitian ini, dapat peneliti simpulkan bahwa peneliti ingin mencari tahu ada tidaknya pengaruh metode latihan kontinu dan interval terhadap peningkatan daya tahan aerobik pemain futsal. Adapun desain dalam menggunakan one group pre-test post-test. 


\section{Hasil dan Pembahasan}

Berdasarkan hasil penelitian yang telah dilakukan latihan kontinu dan interval. Data tersebut menunjukan bahwa metode latihan kontinu dan interval memberikan peningkatan rata-rata dari tes awal hanya 41.3 kemudian setelah diberikan perlakukan adanya peningkatan menjadi 45.2 atau selisih skor rata-rata 4. Untuk lebih jelasnya tertera pada Tabel 1 dibawah ini.

Tabel 1. Statistik Dekriptif

\begin{tabular}{lrrrr}
\hline \multicolumn{5}{c}{ Statistics } \\
\hline & PRETEST & POSTEST & \multicolumn{1}{l}{ PENINGKATAN } \\
\hline$N$ & 12 & 12 & 12 \\
& Valid & 5 & 5 & 5 \\
\hline Mean & 41.3083 & 45.2833 & 4.0000 \\
Std. Error of Mean & 1.44586 & 1.09958 & .43082 \\
Median & 39.2000 & 43.9000 & 4.3500 \\
\hline Mode & 36.80 & $40.50^{\mathrm{a}}$ & $1.20^{\mathrm{a}}$ \\
Std. Deviation & 5.00862 & 3.80904 & 1.49241 \\
\hline Variance & 25,086 & 14,509 & 2,227 \\
Range & 13.50 & 11.10 & 4.90 \\
\hline Minimum & 36.40 & 40.50 & 1.20 \\
Maximum & 49.90 & 51.60 & 6.10 \\
Sum & 495.70 & 543.40 & 48.00 \\
\hline
\end{tabular}

Hasil pengujian normalitas pada tes awal dan tes akhir terhadap sampel dapat dilihat pada tabel 2 dibawah ini:

Tabel 2. Uji Normalitas

\begin{tabular}{ccccc}
\hline Periode Tes & N & Sig $(\rho)$ & $\alpha$ & Hasil \\
\hline Tes Awal & 12 & 0.141 & 0.05 & Normal \\
Tes Akhir & 12 & 0.200 & 0.05 & Normal \\
\hline
\end{tabular}

Dari tabel 2 di atas, terlihat Asymp Sig (2-tailed) sebesar $0.141>0,05$ atau probabalitas 0.141 lebih besar dari 0,05, sehingga hipotesis nol diterima, dengan demikian tes awal berdistribusi normal. Sedangkan hasil data tes akhir terlihat Asymp Sig (2-tailed) sebesar $0.200>0,05$ atau probabalitas 0.200 lebih besar dari 0,05 , sehingga hipotesis nol diterima, dengan demikian tes akhir berdistribusi normal.

Hasil pengujian homogenitas tes awal dan tes akhir sampel dapat dilihat pada tabel 3 dibawah ini:

Tabel 2. Uji Homogenitas

\begin{tabular}{ccccccc}
\hline Periode Tes & $\mathrm{N}$ & F-Hitung & F-Tabel & Sig & $\alpha$ & Hasil \\
\hline Tes Awal dan Akhir & 12 & 7.87 & 3.98 & 0.535 & 0,05 & Homogen \\
\hline
\end{tabular}


Dari tabel 3 di atas didapat tes bleep-test tes awal dan akhir daya tahan aerobik melalui metode latihan kontinu dan interval yaitu $F_{\text {Hitung }}=7.87$ dengan taraf nyata $\alpha=0,05$ sedangkan dari daftar Tabel yaitu $F_{\text {hitung }}=7.87$ yang lebih besar dari pada $F_{\text {tabel }}=3.98$. Dari nilai probabalitasnya $0.535>0,050$ maka hasil data homogen, sehingga hipotesis nol diterima artinya ada perbedaan rata-rata secara nyata hasil tes awal dan tes akhir pada bleep-test.

Hasil pengujian kesamaan dua rata-rata tes akhir sampel dapat terlihat pada tabel 4 dibawah ini:

Tabel 4. Uji Hipotesis

\begin{tabular}{ccccc}
\hline Periode Tes & $\mathrm{N}$ & $\mathrm{t}$-Hitung & $\mathrm{t}$-Tabel & Hasil \\
\hline Selisih Tes Awal dan Tes Akhir & 12 & 9.326 & 1.782 & Signifikan \\
\hline
\end{tabular}

Karena nilai $\mathrm{t}_{\text {Hitung }}=9.326$ lebih besar daripada nilai $\mathrm{t}_{\text {-Tabel }}=1.782$. Dengan demikian hipotesis diterima atau terdapat pengaruh signifikan metode latihan kontinu dan interval terhadap daya tahan aerobik pemain futsal xshoes. Berdasarkan nilai $t$ hitung yang diperoleh, metode latihan kontinu dan interval memberikan pengaruh terhadap daya tahan aerobik pemain futsal $x$ shoes.

Latihan kontinu dan latihan interval merupakan latihan meningkatkan daya tahan aerobik. Latihan kontinu dan latihan interval banyak menekankan pada aktivitas daya tahan. Seperti yang dijelaskan menurut Harsono (2018) menjelaskan bahwa, latihan kontinu yaitu lari terus-menerus tanpa istirahat, dan yang biasanya berlangsung untuk waktu yang lama. Lari terus-menerus yang lebih dari 30 menit dengan tempo yang sedang dibawah ambang rangsang anaerobik akan menghasilkan adaptasi aerobik dengan baik.

Latihan kontinu dilakukan 30 menit tanpa istirahat. Sehingga, kemampuan kerja organ-organ tubuh akan lebih optimal pada aktivitas yang dilakukan dalam jangka waktu yang lama atlet akan tetap bugar tanpa mengalami kelelahan fisik yang berarti. Atlet yang memiliki daya tahan yang baik akan dapat menentukan irama dan pola permainan, memelihara atau mengubah pola permainan sesuai dengan yang diinginkan, dan berjuang secara ulet serta tidak mudah menyerah selama bertanding. Pada puncaknya, atlet akan dapat mencapai prestasi yang bagus. Kemudian, dengan latihan interval seperti yang dikatakan menurut Emral (2017) menjelaskan bahwa, pada metode latihan interval lebih mengutamakan pemberian waktu interval (istirahat) pada saat antar set, dengan bentuk 
aktivitas antara lain dapat dengan cara berlari dan berenang. Sasaran utama pada latihan interval adalah kebugaran energi.

Besarnya sumbangan latihan kontinu dan latihan interval terhadap daya tahan aerobik pada permainan futsal di club $x$ shoes diketahui dengan cara nilai R (r2 x 100\%). Nilai 2 sebesar 0,733 , sehingga besarnya sumbangan latihan kontinu dan interval terhadap daya tahan sebesar 73,3\%, sedangkan sisanya sebesar 26,7\% dipengaruhi oleh faktor lain yang tidak diteliti dalam penelitian ini, yaitu faktor asupan makanan dan faktor lainnya. Sedangkan untuk faktor keberhasilan teknik dilihat dari setelah memberikan perlakuan aspek teknik $80 \%$ dan taktik $75 \%$.

Kefektifan penggunaan metode latihan kontinu dan interval menunjukan hasil yang maksimal dalam meningkatkan daya tahan aerobik pemain futsal. Dari hasil pengamatan selama perlakuan diberikan pemain futsal tanpa mengalami kelelahan yang berarti saat melakukan permainan futsal. Berdasarkan dari data hasil tes dapat dibuktikan yang mana pada hasil tes awal sebelum diberikan perlakuan 41.3 dan setelah diberikan perlakuan metode latihan kontinu dan interval menjadi 45.2 artinya dari data tes tersebut menunjukan adanya peningkatan daya tahan atlet 4 . Selain dari data tes, peningkatan daya tahan pemain futsal dikuatkan pula dari hasil uji hipotesis nilai $t_{\text {-Hitung }}=9.326$ lebih besar daripada nilai $\mathrm{t}_{\text {-Tabel }}=1.789$ atau hipotesis diterima. Berdasarkan nilai $\mathrm{t}$ hitung yang diperoleh di atas, maka dapat disimpulkan bahwa metode latihan kontinu dan interval berpengaruh signifikan terhadap daya tahan pemain futsal atau dengan kata lain hipotesis penelitian dapat diterima.

\section{Kesimpulan}

Dengan demikian hipotesis diterima atau perlakuan dengan menggunakan metode latihan kontinu dan latihan interval berpengaruh signifikan dalam meningkatkan daya tahan aerobik pada club futsal $x$ shoes. Berdasarkan nilai t hitung yang diperoleh di atas, maka dapat disimpulkan bahwa metode latihan kontinu dan interval berpengaruh signifikan terhadap daya tahan pemain futsal atau dengan kata lain hipotesis penelitian dapat diterima.

\section{Daftar Pustaka}

Arifin, J. (2017). SPSS 24 Untuk Peneltian dan Skripsi. Jakarta: PT Rineka Cipta. 
Arikunto, S. (2013). Prosedur Penelitian. Jakarta: PT Rineka Cipta.

Aryanti. (2009). Status Kebugaran Kardiorespirasi Pemain Sepak Bola Wanita PSW Putri Mataram Sleman Yogyakarta. Skripsi. Yogyakarta: Universitas Negeri Yogyakarta.

Narti, A. (2009). Futsal. Bandung: PT Indahjaya Adipratama.

Badriah, D. L. (2012). Metodologi Penelitian Ilmu-Ilmu Kesehatan. Bandung: Multazam.

Emral. (2017). Pengantar Teori \& Metodologi Pelatihan Fisik. Depok: Kencana.

Harsono. (2018). Latihan Kondisi Fisik Untuk Atlet Sehat Aktif. Bandung: PT. Remaja Rosdakarya.

Ismaryati. (2008). Tes Dan Pengukuran Olahraga. Surakarta: LPP UNS dan UNS Press.

Lhaksana, J. (2011). Taktik dan Strategi Futsal Modern. Jakarta. Be Champion.

Mylsidayu, A \& Kurniawan, F. (2015). Ilmu Kepelatihan Dasar. Bandung. Alfabeta.

Nurhasan \& Cholil, H. (2007). Tes dan Pengukuran Keolahragaan. Bandung: FPOK-UPI.

Sukmadinata. (2013). Prosedur Penelitian. Jakarta. PT Rineka Cipta.

Sunarno, A \& Syaifullah, S. (2011). Metodologi Penelitian Keolahragaan. Surakarta: Yuma Pustaka.

Universitas Majelangka. (2019). Panduan Penulisan Karya Ilmiah. Majalengka: UNMA 